\title{
Ghanaian BSW Students' Perceptions of Poverty and Social Welfare Policies in Ghana
}

\author{
Jason T. Castillo \\ Samuel Asante \\ Peter Dwumah \\ Jonas Asamanin Barnie \\ David Becerra
}

\begin{abstract}
In August 2010, data for this exploratory study were drawn from a sample of 185 undergraduate social work students from a public university in Ghana. Ordinal logistic regressions were run to analyze the relationship between social work students' demographic variables and their perceptions toward poverty and social welfare policies in Ghana. The results of this study found that social work students' age, gender, marital status, number of children, socioeconomic status, and area of concentration affected their perception toward poverty and social welfare policies in Ghana. The findings of this study point to several areas for consideration when developing or revising social work education curricula in Ghana.
\end{abstract}

Keywords: Social work students, poverty, social welfare policies, Ghana

Since gaining independence in 1957, Ghana has emerged as a shining example of a developing nation for the rest of the African continent. Located in the western part of Sub-Saharan region, Ghana, home to approximately 24 million people, is a nation with democratic norms entrenched in an active civil society, laws and rules that are respected, a well-managed economy, and a burgeoning middle class (CIA World Factbook, 2011a; CIA World Factbook, 2011b; Ghana Statistical Service [GSS], 2009; Throup, 2011). However, despite the social and political gains that have been achieved, approximately $28 \%$ of Ghanaians live in poverty and the nation remains well below the average of other nations on a number of health indicators including high malnutrition rates, high illiteracy rates, high communicable disease rates, inequities in immunizations among one-year olds, inequities in under-five mortality rates, poor health and sanitation facilities, and inadequate water supplies (Index Mundi, 2010; International Labor Organization [ILO], 2006; Rolleston, 2011; United States Agency for International Development [US AID], 2010; World Health Organization [WHO], 2009).

In Ghana, the reduction of poverty and deprivation among vulnerable citizens was initially the responsibility of the traditional social support system-extended family members and clans (Blavo \& Apt, 1997). Marriage, family, and religion are the foundation of Ghanaian society and serve as the most durable forms of social and economic security to Ghanaians (Laird, 2011; Takyi, Obeng-Gyimah, \& Addai, 2006).

Jason T. Castillo, Ph.D, is an Assistant Professor and Samuel Asante is a doctoral student (Ph.D.) in the College of Social Work at the University of Utah in Salt Lake City. Peter Dwumah and Jonas Asamanin Barnie are faculty member lecturers in the Department of Sociology and Social Work at the Kwame Nkrumah University of Science and Technology in Kumasi, Ghana. David Becerra, Ph.D, is an Assistant Professor in the School of Social Work at Arizona State University in Phoenix.

Copyright @ 2013 Advances in Social Work Vol. 14 No. 2 (Fall 2013), 477-500 
Consisting of far-reaching reciprocal duties, obligations and responsibilities to one another, marriage, family, and religion render moral, spiritual, emotional, financial, and instrumental support to all Ghanaians (Avandel, 2011; Sultan \& Schrofer, 2008). However, following the industrialization and urbanization of the nation, the traditional social support system has not been able to adequately respond to or meet the needs of the impoverished and vulnerable Ghanaians (Kreitzer, 2004). In response to these socioeconomic issues, successive public, private, and non-governmental organizations inclusive of the work of social work professionals have throughout the past few decades developed and implemented various economic and social initiatives intended to reduce the rate of poverty and deprivation among Ghanaians in Ghana.

Since the early 1960s, the Government of Ghana (GOG), either independently or in cooperation with the private sector, non-government organizations, and/or private donors, has assumed responsibility in the reduction of poverty in Ghana. In the 1960s, the GOG emphasized public industrialization strategies in urban areas that were focused on expanding and improving labor, educational, and health care opportunities for Ghanaians in urban areas (Aryeetey \& Goldstein, 2000; Kormey, 2009; Obeng, 2008; Social Security and National Insurance Trust, 2011). In the 1970s, the GOG emphasized local public industrialization strategies in rural areas that were focused on expanding and improving agricultural production rates, farm incomes, and the provision of water and farmer education (Aryeetey \& Goldstein, 2000; Whitefield, 2009). Most recently, beginning in the 1980s, the GOG in cooperation with and receipt of support from the World Bank (WB) and International Monetary Fund (IMF) has emphasized the need to achieve macroeconomic stability across the nation (Aryeetey \& Goldstein, 2000; Devereux et al., 2008; Sowa, 2002).

Unfortunately, due to the growing mass of people leaving rural areas to urban areas, growing incongruity between the human capital of the population and the economic and social development initiatives of the state, increasing decision-making imbalance between the GOG and non-government organizations, and the GOG's decreasing political and monetary support of the public social sector, these initiatives have largely failed to achieve what they were intended to do, decrease the rate of poverty and deprivation among millions of Ghanaians (Adema, Gray \& Kahl, 2003; Armah, 2009; Aryeetey \& Goldstein, 2000; Avendal, 2011; Kreitzer, Abukari, Antonio, Mensah, \& Kwaku, 2009), increase the rate of health insurance coverage among Ghanaians (Sultan \& Schrofer, 2008), and decrease gender disparities in the labor, educational, and government sectors of Ghana (Amu, 2006; Apt, 2007; Heintz, 2005; International Fund for Agricultural Development [IFAD], 2011; Kimani \& Kombo, 2010; Owusu \& Abdulai, 2009).

While the abovementioned initiatives have not yielded the intended results, the initiatives have led the GOG to adopt and integrate different and innovative approaches and systems into the traditional social support system in Ghana, one of these being the institutionalization of a formal bureaucratic social welfare system, which was inclusive of the social work profession. In Ghana, social work is a combination of traditional and Western-imported methods and techniques (Avendal, 2011). In pre-colonial Ghana, social problems were addressed within the context of the traditional system, particularly 
the extended family system, which ensured security for and cohesion among members, provided mechanism for regulating human behavior, and controlled the economic life of individuals (Avendal, 2011, Blavo \& Apt, 1997). Following periods of industrialization and urbanization in Ghana, new social problems emerged, problems the traditional system was neither equipped for nor capable of managing effectively. To this end, the formal social welfare system inclusive of the GOG and social work profession emerged as an alternative social support system to improve the health and well-being of Ghanaian individuals and families in need-educational, employment, health, income, and social welfare services (Blavo \& Apt, 1997). Although no single unifying Western-or African-social work theory or practice exists, Western European ideas and models emphasizing individuals and psychotherapy have continued to prevail in the education of social work students and practitioners in Ghana (Asamoah, 1997; Avendal, 2011; Blavo \& Apt, 1997; Kreitzer et al., 2009; Leighninger \& Midgley, 1997; Midgley, 1981).

According to the International Federation of Social Worker Code of Ethics (IFSW) (2012), "Professional social workers are dedicated to service for the welfare and selffulfillment of human beings; to the development and disciplined use of scientific knowledge regarding human behaviour and society; to the development of resources to meet individual, group, national and international needs and aspirations; to the enhancement and improvement of the quality of life of people; and to the achievement of social justice” (p. 1). Despite this stated mission, evidence suggests that social work professionals across the world are distancing themselves from working with poor and impoverished populations and instead working with moderate income populations and populations with non-chronic emotional issues (Bullock, 2004; Clark, 2007; Hackett, Kuronen, Metthies, \& Kresal, 2003; Limb \& Organista, 2003; Ljubotina \& Ljubotina, 2007; Weiss, 2005; Weiss, Gal, \& Cnaan, 2004; Weiss, Gal, Cnaan, \& Majiaglic, 2002). Contributing further to this issue is evidence indicating that social work students are more often being trained as micro practitioners specializing in counseling with an emphasis on psychotherapy with individuals, groups, and families (Asquith, Clark, \& Waterhouse, 2005; Weiss, 2006) rather than macro practitioners specializing in policy practice and community organization with an emphasis on the political, economic, historical, social, and cultural understanding of populations, organizations, and communities (Jacobson, 2001).

With the economic and social challenges impacting millions of Ghanaians, the formal bureaucratic social welfare system (Kreitzer et al., 2009), and number of social work students graduating from social work educational programs and employed by the abovementioned social welfare system in Ghana, it is essential that researchers examine Ghanaian social work students' perceptions of poverty and social welfare policies in Ghana. The implications associated with the findings of this research will contribute to the: education and development of social work students; professionalization of social work students; short- and long-term viability and sustainability of social work educational programs; and the short- and long-term viability and sustainability of the social welfare policies and programs for poor and impoverished individuals, families, and communities in Ghana. 


\section{Literature Review}

Throughout the years, numerous studies have examined social work students' perceptions of poverty and social welfare policies in their respective countries. A majority of these studies have occurred with social work students in developed nations and focused on factors ranging from students' age, gender, race, ethnicity, nationality, socioeconomic status, place of residence, political assumptions, educational status, to course of study (i.e., BSW, MSW) (Ljubotina \& Ljubotina, 2007; Nasser, Abouchedid, \& Khashan, 2002; Weaver \& Yun, 2010; Weiss, 2005, 2006). Missing from this research has been the examination of social work students in developing nations. Given the limited amount of research on social work students in developing nations, the following literature review consists of literature primarily from developed nations but also inclusive of several developing nations including Croatia, Hungary, and Zimbabwe.

\section{Social Work Students’ Perceptions of Poverty}

Feagin (1975) was one of the first researchers to systematically examine the beliefs and causes of poverty among different subgroups. He found 11 types of beliefs about the causes of poverty, which were later grouped into three categories. The first category attributed poverty to individual or internal causes-a specific lifestyle of the poor, such as lack of capability, effort, and laziness, or alcohol abuse. The second category attributed poverty to structural or external causes - unfriendly social, political, cultural, and economic factors such as uneven distribution of wealth, exploitation of the poor, or unequal opportunities. The third category attributed poverty to fatalism-bad luck, illness, fate, or God's will. Of these categories, the individualistic and structural categories have dominated the social, political, and economic landscape of nations worldwide, resulting in policy and program initiatives aligned with each respective category.

Social work students have maintained a variety of opinions or beliefs about poverty and poor populations many of which are similar to those mentioned previously. In a study comparing the attitudes regarding poverty among college students in South Africa, Lebanon, and Portugal, South African students were more likely to blame the individual for their poverty than their Portuguese and Lebanese counterparts (Nasser et al., 2002). In a cross-national comparison study of social work students, Weiss (2006) found that Brazilian students were more likely to attribute poverty to structural factors than were students from the other six nations. In their cross-national and cross-discipline study of undergraduate students, Ljubotina and Ljubotina (2007) found that compared to undergraduate agriculture and economics students, undergraduate social work students were less likely to attribute poverty to an individual's personal characteristics. In their study comparing undergraduate social work and business students' attitudes toward poverty, Weaver and Yun (2010) found that students who were female or with more leftist political views were more likely to attribute poverty to structural factors. In a cross-national study examining social work graduates attitudes toward poverty and the goals of the social work profession, Weiss (2005) found that Hong Kong social work graduates attributed greater importance to psychological explanations of poverty and that Australian social work graduates were more inclined than the Brazilian, Israeli, German, 
Hungarian, Zimbabwean, and American social work graduates to attribute poverty to structural causes.

\section{Social Work Students' Perceptions of Social Welfare Policies}

According to Muuri (2010), social welfare policy is regarded as a way to support the less fortunate and to distribute life's uncertainties more equally among different social groups. Similarly, Breznau (2008) associated social welfare policy with the state's provision of health, education, shelter, and employment services to the general public. There have been several arguments regarding the relevance of social welfare policies in contemporary societies. While some individuals and groups accept and support the development and implementation of social welfare policies and programs, others vehemently oppose them (Breznau, 2008). For supporters of social welfare policies, social welfare policy is a means to help out the least fortunate or poorest members of the society by creating or increasing social equality (Breznau, 2008). Brown and Neku (2005) emphasized in their study that welfare policies seek to alleviate poverty among the most vulnerable and marginalized majority groups who have the lowest income and possess the least education and highest unemployment rates. Findings from their study showed that participants who supported social welfare policies in the form of poverty alleviation programs believed welfare policies promote self-reliance.

For those opposing social welfare policies, social welfare policy is detrimental to society and has done little or failed to reduce poverty. In his analysis of social welfare programs, Murray (1984) found that social welfare policies and programs can lead to an increase in the rate of social problems such as poverty and crime. The study promoted individual initiative rather than government intervention to help low income populations meet the basic needs of life and insisted on a discontinuation of social welfare policies and programs. Dollar and Kraay (2000) asserted that a market economy emphasizing economic development is essential for growth and protection of the poor, whereas the provision of support through social welfare policies and programs have an undesirable effect on society. According to Tanner (2012), despite nearly \$15 trillion in total social welfare spending since the War on Poverty was declared in the United States in 1964, the poverty rate is perilously close to where it was more than 40 years ago with a poverty rate of $15 \%$.

Unlike the previous section where there have been a few studies examining social work students' perceptions of poverty, less work has been done examining social work students' perceptions of social welfare policies. However, a body of research examining social work students' perceptions of the role of government in addressing social issues in various societies does exist (Tam, 2003; Weiss, 2003, 2006; Weiss, Cnaan, \& Gal, 2005; Weiss et al., 2002; Woodcock \& Dixon, 2005). The results of these studies have been mixed with some groups supportive and other groups less supportive of the government intervening in social issues, such as the alleviation of poverty.

In a study comparing 429 first year social work students' preferences of social policy for dealing with the needs of citizens in three countries - the United Kingdom, Israel, and the United Sates, Weiss and colleagutes (2002) found that the social work students 
supported government intervention in the areas of housing, welfare, and redistribution of wealth. However, there was variation among students in regard to the degree of government support, with some students highly supportive and others less supportive of government intervention. Students from all three of the universities responded with much indifference to their willingness to fund the welfare state and its program. In a study involving 239 social work graduates in Hong Kong and the People's Republic of China, Tam (2003) found that while some social work students perceived the government as being responsible for the alleviation of social problems in society, other students perceived individuals as being responsible for the alleviation of their own social problems. In a study with 138 undergraduate social work students in Israel, Weiss (2003) found that social work students favored government social welfare programs as a means for dealing with poverty-related problems.

In another study examining 223 undergraduate and graduate social work students at two universities in two countries, the United States and Israel, Weiss and colleagues (2005) found that social work students were supportive of the welfare state model. Social work students in both nations indicated that the state should be responsible for welfare services for its citizens. However, social work students in the United States demonstrated more willingness to pay for the welfare state than their Israeli counterparts, even though the level of support cannot be described as very high. In a study examining 781 final year social work students at leading schools of social work from ten countries, Woodcock and Dixon (2005) found that social work students expressed strong support for the state to intervene in alleviating poverty. Preference for state intervention was highest among social work students in Australia, Hong Kong, and the United States. The degree of difference in level of support for state intervention was greatest in Brazil, Australia, and Canada and smallest in Zimbabwe and Hong Kong.

In a third study examining 514 graduating Bachelor's of Social Work students from five countries: Brazil, Germany, Hungary, Israel, and the United States, Weiss (2006) found that social work students were more inclined to view the expansion of state government welfare provisions as the best means of dealing with poverty and less inclined to support the reduction of state government intervention in dealing with poverty. Interestingly, with respect to extending state welfare assistance, Brazilian social work students were more supportive of extending state provision than social work students in the other four nations. While the abovementioned literature is beneficial to understanding social work students' perceptions toward poverty and social welfare policies, a majority of these studies have been conducted with social work students in developed nations with established social welfare systems. Relatively little research has been conducted with social work students in developing nations, nations with substantial amounts of poverty and less developed social welfare systems. As such, this study will be the first to examine Ghanaian undergraduate social work students' perceptions of poverty and social welfare policies in Ghana. 


\section{Purpose of the Study}

To contribute to the abovementioned research, the goals of this exploratory study were to: (1) provide descriptive information about a sample of undergraduate social work students in Ghana, (2) examine the relationship between Ghanaian social work students' socio-demographic characteristics and their perception of poverty in Ghana, and (3) examine the relationship between Ghanaian social work students' socio-demographic characteristics and their perception of social welfare policies in Ghana. Given the economic and social challenges impacting millions of Ghanaians, as well as the emerging development of the social work profession in Ghana, the researchers deemed it important that further research be conducted with this population on this particular area of study.

\section{Methodology}

\section{Design of Study}

In August 2010, the researchers collected data from a convenience sample of undergraduate social work students enrolled in an accredited social work program at a university in Ghana. This study received Institutional Review Board (IRB) approval from the first author's U.S. institution and permission to conduct the study was received from department administrators at the participating university in Ghana. The study required that participants complete a 42-item questionnaire consisting of five sections addressing: descriptive information (i.e., age, gender, marital status, number of children, socioeconomic status, and area of concentration); perceptions of the cause of poverty; perceptions of social welfare policies in Ghana; perceptions of government response to poverty; and perceptions of social work policy education in the social work curriculum. Administration of the questionnaires occurred during the undergraduate policy courses in the fall semester. Participants were informed that the questionnaire would take about 10 minutes to complete, there were minimal risks associated with the study, and there were no direct benefits for participating in the study.

\section{Measures}

Dependent Variables. The dependent or outcome variables in this study consisted of 10 items asking social work students about their perceptions toward poverty and social welfare policies in Ghana. The first five items of the questionnaire consisted of questions asking students about their perceptions of the causes of poverty. Using a 5-point Likert scale, students were asked whether they $1=$ Strongly Disagree to $5=$ Strongly Agree that (1) Poverty is caused by a lack of motivation, self-discipline, and work-ethic, (2) Poverty is caused by social and structural forces (i.e., inequality), (3) People are poor because they belong to oppressed populations, (4) People are poor because they do not have equal opportunities, and (5) People are poor because they do not want to work. The remaining items of the questionnaire consisted of questions asking students about their perceptions of social welfare policies in Ghana. Using a 5-point Likert scale, students were asked whether they $1=$ Strongly Disagree to $5=$ Strongly Agree that (1) Social welfare policies have benefitted my family, (2) Social welfare policies have a positive impact on society, (3) Social welfare policies mostly benefit the poor, (4) Social welfare benefits increase 
poor families' dependence on society, and (5) Social welfare benefits undermine individuals' willingness to work.

Independent Variables. The independent variables in this study consisted of seven items asking social work students about their age, gender, marital status, number of children, socioeconomic status, and area of concentration. Age was a categorical variable with four response categories ranging from $0=21-30$ to $3=51-60$. Gender was a categorical variable with two response categories, $0=$ Male and $1=$ Female. Marital status was a categorical variable with two response categories, $0=$ Not Married to $1=$ Married. Number of children was a categorical variable with two response categories, $0=$ No Children and $1=$ One or more Children. Socioeconomic status was a categorical variable with two response categories, $0=$ Very Poor-Fair and $1=$ Good-Very Good. Area of concentration was a categorical variable with two response categories, $0=$ Micro social work concentration and 1 = Macro social work concentration.

\section{Characteristics of the Sample}

A total of 185 social work students in their third year (i.e., junior year) of college education participated in this study (65 females, 119 males) (see Table 1). Sixty-one percent of the participants were between 21-30 years of age. A majority of the participants were single (68\%) and almost one-third of the participants were married (29\%). Sixty-three percent of the participants reported having no children.

\section{Table 1. Characteristics of Participating Ghanaian Social Work Students}

\begin{tabular}{llrr}
\hline & & N & Percent (\%) \\
\hline Age (years) & $21-30$ & 104 & 61 \\
& $31-40$ & 54 & 31 \\
& $41-50$ & 11 & 6 \\
Gender & $51-60$ & 3 & 2 \\
\multirow{4}{*}{ Marital Status } & Female & 65 & 35 \\
\multirow{5}{*}{ Number of Children } & Male & 119 & 65 \\
& Not Married & 126 & 70 \\
Socioeconomic Status & None & 54 & 30 \\
& Some & 90 & 63 \\
Area of Concentration & 53 & 37 \\
& Good-Very Good & 83 & 46 \\
& Micro & 98 & 54 \\
& Macro & 33 & 18 \\
\hline
\end{tabular}

Note: Because of missing data the totals do not equal the specified $\mathrm{N}=185$ 
Forty-six percent of the participants reported having very poor-fair household incomes as adults. Based on the overall mean scores, participants on average tended to agree that in Ghana, people are poor because they do not have equal opportunities $(M=$ 3.87), poverty is caused by social and structural forces $(M=3.85)$, and social welfare policies have a positive impact on society $(M=3.93)$ (see Table 2 ).

Table 2. Mean Scores on Ghanaian Social Work Students' Perceptions of Poverty and Social Welfare Policies in Ghana

\begin{tabular}{lcccc}
\hline & N & Mean Scores & SD & Range \\
\hline Perceptions of Poverty & & & & \\
Lack of Motivation & 184 & 3.29 & 1.141 & $1-5$ \\
Social and Structural Forces & 182 & 3.85 & 1.005 & $1-5$ \\
Belong to Excluded Populations & 179 & 2.96 & 1.242 & $1-5$ \\
Unequal Opportunities & 178 & 3.87 & 1.140 & $1-5$ \\
Do Not Want to Work & 182 & 2.73 & 1.430 & $1-5$ \\
& & & & \\
Perceptions of Social Welfare Policies & & & & \\
Benefit Family & 184 & 2.96 & 1.101 & $1-5$ \\
Positive Impact on Society & 182 & 3.93 & 0.854 & $1-5$ \\
Benefit the Poor & 184 & 2.62 & 1.209 & $1-5$ \\
Increase Poor Families' Dependence on Society & 181 & 2.91 & 1.189 & $1-5$ \\
Undermine Individual's Willingness to Work & 184 & 2.40 & 1.155 & $1-5$ \\
Encourage Idleness among the Poor & 181 & 2.61 & 1.281 & $1-5$ \\
\hline
\end{tabular}

\section{Analysis Plan}

Using Predictive Analytics Software (PASW) 18, several statistical procedures were used in this study, including Spearman correlation coefficient tests and Ordinal logistic regressions. Bivariate analyses including Spearman correlation coefficient were used to determine the strength of the relationship between the independent and dependent variables. Ordinal logistic regression was used to predict the outcome of social work students' perceptions toward poverty and social welfare policies (categorical criterion variables with more than two response categories) based on social work students age, gender, marital status, number of children, socioeconomic status, and area of concentration (predictor variables).

\section{Results}

\section{Bivariate Analyses}

Several Spearman correlation coefficient tests were conducted to determine the strength of the relationship between social work students' age, gender, marital status, number of children, socioeconomic status, area of concentration and their perceptions toward poverty and social welfare policies in Ghana (see Table 3). A significant relationship $($ rho $(169)=-.162, \mathrm{p}<.05)$ was found between social work students' age and 
perception toward poverty-lack of motivation. Older social work students tended to disagree that poverty was due to a lack of motivation. A significant relationship (rho(139) $=.207, \mathrm{p}<.05$ ) was found between social work students' number of children and perception toward poverty-social and structural forces. Social work students with more than one child tended to agree that poverty was due to social and structural forces. A significant relationship $(r h o(175)=-.159, \mathrm{p}<.05)$ was found between social work students' area of concentration and perception toward poverty-belonging to an excluded population. Social work students in the macro area of concentration tended to disagree that poverty is due to belonging to an excluded population. Finally, a significant relationship $(r h o(139)=-.223, p<.01)$ was found between social work students' socioeconomic status and perception toward poverty - do not have equal opportunities. Social work students with higher socioeconomic status tend to disagree that poverty is due to unequal opportunities. No significant relationships were found between social work students' age, gender, marital status, number of children, socioeconomic status, area of concentration and their perceptions toward social welfare policies in Ghana.

\section{Ordinal Logistic Regression Analyses}

Table 4 presents the results of the ordinal logistic regression analyses examining social work students' perceptions toward poverty. The log of the odds of poverty being due to lack of motivation was negatively related to social work students' age $(p<.05)$. That is, older social work students were less likely to perceive that poverty is due to lack of motivation. Students were asked whether they $1=$ Strongly Disagree to $5=$ Strongly Agree that "Poverty is caused by a lack of motivation, self-discipline, and work-ethic." The results indicated that for every one unit increase in the age category there was a $48 \%$ lower likelihood of choosing a higher category $(\mathrm{OR}=.52)$. In other words, there is a negative association between social work students' age and their perception that poverty was due to lack of motivation. The log of the odds of poverty being due to social and structural forces was positively related to the social work students' number of children ( $p$ $<.05)$. Social work students with one or more children were more likely to perceive that poverty is due to social and structural forces. For every one unit increase in the number of children category there was a $264 \%$ greater likelihood of choosing a higher category indicating poverty as being due to social and structural forces $(\mathrm{OR}=3.64)$.

The log of the odds of poverty being due to belonging to an excluded population was negatively related to social work students' area of concentration $(p<.01)$. Macro-focused social work students were $68 \%$ less likely to perceive that poverty is due to belonging to an excluded population (OR $=.32$ ). The log of the odds of poverty being due to unequal opportunities was negatively related to social work students' socioeconomic status ( $p<$ .05 ). Social work students with good-very good socioeconomic status were less likely to perceive that poverty is due to unequal opportunities $(\mathrm{OR}=.48)$. The log of the odds of poverty being due to not wanting to work was positively related to social work students' marital status $(p<.05)$. Married social work students were much more likely to perceive that poverty is due to persons not wanting to work $(\mathrm{OR}=3.13)$. 
Table 3. Bivariate Correlations (Spearman rho) among Ghanaian Social Work Students' Perceptions of Poverty and Social Welfare Policies

\begin{tabular}{|c|c|c|c|c|c|}
\hline & $\begin{array}{c}\text { Lack of } \\
\text { Motivation }\end{array}$ & $\begin{array}{l}\text { Social and } \\
\text { Structural Forces }\end{array}$ & $\begin{array}{l}\text { Belong to Excluded } \\
\text { Populations }\end{array}$ & $\begin{array}{l}\text { Do not have Equal } \\
\text { Opportunities }\end{array}$ & Do not want to Work \\
\hline Age & $-.162^{*}$ & .129 & .046 & .064 & -.056 \\
\hline Gender & -.070 & -.061 & -.022 & -.031 & .129 \\
\hline Marital Status & -.093 & .084 & .137 & .030 & .089 \\
\hline No. Children & -.117 & $.207^{*}$ & .031 & -.013 & .014 \\
\hline SES & .061 & -.037 & -.099 & $-.223^{* *}$ & .066 \\
\hline \multirow[t]{2}{*}{ Concentration } & .108 & -.041 & $-.159^{*}$ & .057 & .021 \\
\hline & Benefits Family & $\begin{array}{l}\text { Positive Impact } \\
\text { on Society }\end{array}$ & Benefit the Poor & $\begin{array}{l}\text { Increase Poor Families } \\
\text { Dependence on Society }\end{array}$ & $\begin{array}{l}\text { Undermine Individual's } \\
\text { Willingness to Work }\end{array}$ \\
\hline Age & .033 & .052 & .026 & -.140 & -.018 \\
\hline Gender & -.020 & -.121 & -.085 & .102 & .042 \\
\hline Marital Status & .093 & .091 & .058 & -.113 & .021 \\
\hline No. Children & .058 & .066 & -.073 & -.146 & .004 \\
\hline SES & .103 & -.114 & .005 & .116 & .080 \\
\hline Concentration & -.019 & .061 & .019 & .098 & .023 \\
\hline$* \mathrm{p}<.05 \quad * * \mathrm{p}<.01$ & $* * * \mathrm{p}<.001$ & & & & \\
\hline
\end{tabular}


Table 4. Ordinal Logistic Regressions: Ghanaian Social Work Students’ Perceptions of Poverty

\begin{tabular}{|c|c|c|c|c|c|c|c|c|c|c|}
\hline & \multicolumn{2}{|c|}{$\begin{array}{c}\text { Lack of } \\
\text { Motivation }\end{array}$} & \multicolumn{2}{|c|}{$\begin{array}{c}\text { Social and } \\
\text { Structural Forces }\end{array}$} & \multicolumn{2}{|c|}{$\begin{array}{l}\text { Belong to Excluded } \\
\text { Populations }\end{array}$} & \multicolumn{2}{|c|}{$\begin{array}{l}\text { Do not have Equal } \\
\text { Opportunities }\end{array}$} & \multicolumn{2}{|c|}{ Do not want to Work } \\
\hline & B & OR & B & OR & $\mathrm{B}$ & OR & B & OR & B & OR \\
\hline Age & $\begin{array}{l}-.645 \\
(.329)\end{array}$ & $.52^{*}$ & $\begin{array}{l}.042 \\
(.340)\end{array}$ & 1.04 & $\begin{array}{l}-.151 \\
(.350)\end{array}$ & .86 & $\begin{array}{l}-.231 \\
(.327)\end{array}$ & .79 & $\begin{array}{l}.067 \\
(.307)\end{array}$ & 1.07 \\
\hline Gender & $\begin{array}{l}-.249 \\
(.381)\end{array}$ & .78 & $\begin{array}{l}-.232 \\
(.384)\end{array}$ & .79 & $\begin{array}{c}-.326 \\
(.362)\end{array}$ & .72 & $\begin{array}{l}-.187 \\
(.376)\end{array}$ & .83 & $\begin{array}{c}.620 \\
(.359)\end{array}$ & 1.86 \\
\hline Marital Status & $\begin{array}{c}.330 \\
(.605)\end{array}$ & 1.39 & $\begin{array}{l}-.409 \\
(.613)\end{array}$ & .66 & $\begin{array}{c}.805 \\
(.676)\end{array}$ & 2.24 & $\begin{array}{c}.347 \\
(.620)\end{array}$ & 1.41 & $\begin{array}{l}1.142 \\
(.581)\end{array}$ & $3.13^{*}$ \\
\hline No. Children & $\begin{array}{l}-.050 \\
(.643)\end{array}$ & .95 & $\begin{array}{l}1.292 \\
(.661)\end{array}$ & $3.64^{*}$ & $\begin{array}{l}-.421 \\
(.657)\end{array}$ & .66 & $\begin{array}{l}-.154 \\
(.657)\end{array}$ & .86 & $\begin{array}{l}-.939 \\
(.610)\end{array}$ & .34 \\
\hline SES & $\begin{array}{l}-. .087 \\
(.364)\end{array}$ & .92 & $\begin{array}{l}.005 \\
(.366)\end{array}$ & 1.00 & $\begin{array}{l}-.186 \\
(.349)\end{array}$ & .83 & $\begin{array}{l}-.739 \\
(.366)\end{array}$ & $.48^{*}$ & $\begin{array}{l}.227 \\
(.336)\end{array}$ & 1.25 \\
\hline Concentration & $\begin{array}{l}.712 \\
(.456)\end{array}$ & 2.04 & $\begin{array}{l}-.530 \\
(.472)\end{array}$ & .59 & $\begin{array}{l}-1.128 \\
(.451)\end{array}$ & $.32^{* *}$ & $\begin{array}{l}.202 \\
(.469)\end{array}$ & 1.22 & $\begin{array}{l}.521 \\
(.432)\end{array}$ & 1.68 \\
\hline $\mathrm{N}$ & \multicolumn{2}{|c|}{127} & \multicolumn{2}{|c|}{126} & \multicolumn{2}{|c|}{122} & \multicolumn{2}{|c|}{121} & \multicolumn{2}{|c|}{126} \\
\hline $\begin{array}{l}* \mathrm{p}<.05 \quad * * \mathrm{p} \\
\text { Standard errors } \\
\text { Gender (Male }= \\
\text { Marital Status (N } \\
\text { Number of Child } \\
\text { Socioeconomic } \\
\text { Area of Concentr }\end{array}$ & $\begin{array}{l}\text { e** } p<.001 \\
\text { esis } \\
=1 \text { ) } \\
\text { ed }=0 \text {, Mar } \\
\text { children }=0 \\
\text { ery Poor-Fa } \\
\text { icro }=0, \mathrm{M}\end{array}$ & $\begin{array}{l}\mathrm{d}=1) \\
\text { One or } \mathrm{N} \\
=0, \mathrm{Go} \\
\text { ro }=1 \text { ) }\end{array}$ & $\begin{array}{l}\text { Very Go } \\
\text { Verildre }\end{array}$ & & & & & & & \\
\hline
\end{tabular}


Table 5. Ordinal Logistic Regressions: Ghanaian Social Work Students’ Perceptions of Social Welfare Policies

\begin{tabular}{|c|c|c|c|c|c|c|c|c|c|c|}
\hline & \multicolumn{2}{|c|}{ Benefits Family } & \multicolumn{2}{|c|}{$\begin{array}{l}\text { Positive Impact } \\
\text { on Society }\end{array}$} & \multicolumn{2}{|c|}{ Benefit the Poor } & \multicolumn{2}{|c|}{$\begin{array}{l}\text { Increase Poor Families } \\
\text { Dependence on Society }\end{array}$} & \multicolumn{2}{|c|}{$\begin{array}{l}\text { Undermine Individual's } \\
\text { Willingness to Work }\end{array}$} \\
\hline & $\mathrm{B}$ & OR & B & OR & B & OR & B & OR & $\mathrm{B}$ & OR \\
\hline Age & $\begin{array}{l}-.220 \\
(.313)\end{array}$ & .80 & $\begin{array}{l}-.176 \\
(.330)\end{array}$ & .84 & $\begin{array}{l}.639 \\
(.322)\end{array}$ & $1.89^{*}$ & $\begin{array}{l}.111 \\
(.333)\end{array}$ & 1.12 & $\begin{array}{l}-.018 \\
(.320)\end{array}$ & .98 \\
\hline Gender & $\begin{array}{l}-.092 \\
(.358)\end{array}$ & .91 & $\begin{array}{l}-.752 \\
(.384)\end{array}$ & $.47^{*}$ & $\begin{array}{l}-.598 \\
(.370)\end{array}$ & .55 & $\begin{array}{l}.265 \\
(.367)\end{array}$ & 1.30 & $\begin{array}{l}.542 \\
(.368)\end{array}$ & 1.72 \\
\hline Marital Status & $\begin{array}{c}.794 \\
(.583)\end{array}$ & 2.21 & $\begin{array}{c}.949 \\
(.624)\end{array}$ & 2.58 & $\begin{array}{l}1.094 \\
(.601)\end{array}$ & 2.99 & $\begin{array}{c}.499 \\
(.610)\end{array}$ & 1.65 & $\begin{array}{c}.584 \\
(.616)\end{array}$ & 1.79 \\
\hline No. Children & $\begin{array}{l}-.188 \\
(.614)\end{array}$ & .83 & $\begin{array}{l}-.352 \\
(.675)\end{array}$ & .70 & $\begin{array}{l}-1.927 \\
(.646)\end{array}$ & $.15^{* * *}$ & $\begin{array}{l}-1.267 \\
(.652)\end{array}$ & $.28^{*}$ & $\begin{array}{l}-.204 \\
(.652)\end{array}$ & .82 \\
\hline SES & $\begin{array}{c}.187 \\
(.342)\end{array}$ & 1.21 & $\begin{array}{l}-.458 \\
(.362)\end{array}$ & .63 & $\begin{array}{c}.338 \\
(.350)\end{array}$ & 1.40 & $\begin{array}{c}.461 \\
(.348)\end{array}$ & 1.59 & $\begin{array}{c}.410 \\
(.352)\end{array}$ & 1.51 \\
\hline Concentration & $\begin{array}{l}.240 \\
(.437)\end{array}$ & 1.27 & $\begin{array}{l}.438 \\
(.460)\end{array}$ & 1.54 & $\begin{array}{l}-.066 \\
(.446)\end{array}$ & .99 & $\begin{array}{l}.801 \\
(.457)\end{array}$ & 2.23 & $\begin{array}{l}.365 \\
(.445)\end{array}$ & 1.44 \\
\hline $\mathrm{N}$ & \multicolumn{2}{|c|}{127} & \multicolumn{2}{|c|}{125} & \multicolumn{2}{|c|}{128} & \multicolumn{2}{|l|}{125} & \multicolumn{2}{|c|}{127} \\
\hline $\begin{array}{l}* \mathrm{p}<.05 \quad * * \mathrm{p} \\
\text { Standard errors i } \\
\text { Gender (Male = } \\
\text { Marital Status (N } \\
\text { Number of Child } \\
\text { Socioeconomic S } \\
\text { Area of Concentr }\end{array}$ & $\begin{array}{l}1 \quad * * * \mathrm{p} \\
\text { enthesis } \\
\text { male }=1 \text { ) } \\
\text { larried }= \\
\text { No childr } \\
\text { s (Very P } \\
\text { (Micro }\end{array}$ & $\begin{array}{l}\text { arried }= \\
0, \text { One } \\
\text { air }=0 \\
\text { Macro }\end{array}$ & $\begin{array}{l}\text { More Chi } \\
\text { od-Very }\end{array}$ & $\begin{array}{l}n=1) \\
o d=1)\end{array}$ & & & & & & \\
\hline
\end{tabular}


According to the models examining social work students' perceptions toward social welfare policies in Ghana (see Table 5), the log of the odds of social welfare policies positively impacting society was negatively related to social work students' gender ( $p<$ .05). Female social work students were less likely to perceive that social welfare policies positively impacted society $(\mathrm{OR}=.47)$. The log of the odds of social welfare policies benefitting the poor was positively related to social work students' age $(p<.05)$. Older social work students were more likely to perceive that social welfare policies benefitted the poor. For every one unit increase in the age category there was an $89 \%$ greater likelihood perceiving that social welfare policies benefit the poor $(\mathrm{OR}=1.89)$.

The log of the odds of social welfare policies benefitting the poor was negatively related to social work students' number of children $(p<.001)$. Social work students with one or more children were less likely to perceive that social welfare policies benefitted the poor. In fact, for every one unit increase in the number of children category there is an $85 \%$ lower likelihood of choosing a higher category indicating that social welfare policies benefit the poor $(\mathrm{OR}=.15)$. The $\log$ of the odds of social welfare policies increasing poor families' dependence on society was negatively related to social work students' number of children $(p<.05)$. Social work students with one or more children were less likely to perceive that social welfare policies increased poor families' dependence on society. In fact, for every one unit increase in the number of children category there is a $72 \%$ lower likelihood of choosing a higher category indicating that social welfare policies increase poor families dependence on society $(\mathrm{OR}=.28)$.

\section{Discussion}

This exploratory study examined Ghanaian undergraduate social work students' perceptions toward poverty and social welfare policies in Ghana. The results of this study found that social work students' age, gender, marital status, number of children, socioeconomic status and area of concentration affected their perception toward poverty and social welfare policies in Ghana. These findings seem relevant to the abovementioned literature and warrant further explanation. The findings indicating that social work students with one or more children were less likely to perceive that social welfare policies benefitted the poor and increased poor families' dependence on society may suggest that social work students with one or more children are aware of the existing social welfare policies and programs and outcomes associated with these social welfare policies and programs. Given this, the social work students may realize that one, the social welfare policies are not benefitting the poor, and two, without getting to or benefitting the poor, poor families cannot in turn become dependent upon society.

The two findings that social work students with one or more children were more likely to perceive that poverty was attributed to social and structural forces and older social work students were less likely to perceive that poverty is due to lack of motivation are consistent with the belief that the nation's institutional infrastructure comprised of informal networks of family members and religious institutions and formal networks including labor, educational, and government sectors are not adequately prepared or structured to respond to the needs impacting millions of poor Ghanaians (Adema et al., 2003; Armah, 2009; Avendal, 2011). Social work students with one or more children may 
themselves be employed, generating an income, and maintaining a household, which come with costs and economic uncertainty, an uncertainty not necessarily of their own doing. With the increased responsibilities and costs associated with adulthood-marriage, parenting, employment, and managing a household—it is reasonable to assume that social work students with one or more children may attribute poverty to social and structural forces because they may believe poor persons are doing all they can with the resources available to them, yet they are or are close to experiencing economic challenges, challenges outside of their individual control.

The finding that female social work students were less likely to perceive social welfare policies as having a positive impact on society may be attributed to the realization that considerable disparities exist between females and males in terms of educational, employment, income, and political opportunities (IFAD, 2011; Owusu \& Abdulai, 2009). When comparing females to males in Ghana, females have less formal education (Apt, 2007), have fewer employment opportunities with lower levels of advancement (Amu, 2006), are concentrated in jobs with lower earnings (Heintz, 2005), and are less represented in administrative and elected positions at the district, local, regional, and national level of government (Kimani \& Kombo, 2010). Given these inequalities, female social work students may not perceive social welfare policies as benefitting women or society. The finding that older social work students were more likely to perceive that social welfare policies benefitted the poor may suggest that older social work students are more knowledgeable and familiar with the principles and goals underlying the existing social welfare policies and programs (Gobah \& Zhang, 2011; Mensah, 2009; Mensah, Oppong, \& Schmidt, 2010). Mindful of their own maturation, as well as accompanying life changes and conditions in life, older social work students may have some trepidation regarding their own short- and long-term security, thereby holding more positive attitudes toward social welfare policies benefitting the poor.

Several findings associated with social work students' marital status, socioeconomic status, and area of concentration seems to diverge from the abovementioned literature and warrant further explanation. The finding that married social work students were more likely to perceive that poverty is due to persons not wanting to work may indicate that married social work students recognize and understand the discipline, sacrifice, and work ethic necessary to sustain a marriage and manage a household; thus they may perceive that people who are poor may be lacking the moral principles of discipline, sacrifice, and work ethic, all of which are necessary to keeping one out of poverty (Johnson, 2010; Otlin, 2008). The finding that social work students of higher socioeconomic status were less likely to perceive that poverty is due to unequal opportunities may suggest that these students believe they amassed all of which they are and have on their own. These students may also believe that persons of moderate or higher socioeconomic status have made good use of their time, are the best and brightest, and utilized to the fullest extent opportunities available to them, whereas persons of lower socioeconomic status did not, therefore they get what they deserve-lower socioeconomic status or poverty. With this, it is reasonable to assume that social work students with good-very good socioeconomic status may be unaware of the privileges and benefits afforded them because of their socioeconomic status. 
Finally, the finding that social work students interested in macro social work practice were less likely to attribute poverty to membership in excluded populations may suggest that social work students interested in macro social work practice may not be entirely aware of or understand the tenets associated with macro social work practice-policy and planning, policy advocacy, and community and organization, most of which acknowledge and account for differences between groups-social stratification. Given the widespread belief that a higher educational degree leads to more power, authority, and prestige in the workforce (Perbi, 2004), the social work students interested in macro social work practice, a majority of whom responded to administration and supervision, may be more motivated by the perceived power, authority, and prestige associated with administrative and supervisory positions rather than the values, principles, and responsibilities associated with macro social work practice.

\section{Limitations}

Although the results of this study provide evidence suggesting that social work students' socio-demographic characteristics were related to their perceptions of poverty and social welfare policies in Ghana, the results should be interpreted with caution, as the study contained several limitations. First, the sample consists of social work students from one social work program in Ghana and is not based on a random probability sample; therefore the results cannot be generalized to all social work students in Ghana. Future research studies may be conducted with social work students at each of the three social work programs in Ghana. Second, this study utilized a cross-sectional design, so changes in social work students' perceptions toward poverty and social welfare policies in Ghana cannot be determined. It would be beneficial to replicate this study using a pre- and posttest design over an extended period of time. Third, the questionnaire that was administered was constructed by the researchers using previous literature and was not tested for construct validity, reliability, and responsiveness of the measures. It would be beneficial to replicate this study using instruments with demonstrated validity and reliability. Fourth, the questionnaire was constructed using items and terms primarily associated with American and Western European cultures and literature. It would be beneficial to refine the questionnaire by using terms that are more familiar to population being examined. Despite these limitations, the results of this study may provide Ghanaian social work program administrators and educators with information that may be further incorporated into their curriculum-poverty, gender issues, family issues, and social welfare policies in Ghana.

\section{Implications}

Given the impact poverty is having on Ghanaians, social work students in Ghana should be introduced to the different definitions associated with poverty, theories of poverty, dimensions of poverty, impact of poverty on individuals, families, groups, organizations, communities, and nations, and impact of social welfare policies on alleviating and/or eliminating poverty among impoverished populations in Ghana. With this, the examination of poverty and social welfare policies in the social work educational curricula should be grounded in a socio-environmental context and encourage social 
work students to think critically about the social, political, economic, historical, and cultural factors of poverty and social welfare policies in Ghana. If social work students practice according to a socio-environmental view, it may lead to an understanding of poverty that is inclusive of both individual and structural factors, as well as inclusive of macro-oriented interventions-social planning and policy, community and organization development, and social and political advocacy. This would be a departure from the approach emphasizing the remediation and rehabilitation of women, homeless children, and persons with a mental illness, physical disability, or both, the approach which has dominated social work practice and education in Ghana (Blavo \& Apt, 1997; Kreitzer, 2004; Kreitzer et al., 2009; Manful \& Manful, 2010). Through this approach, social work students may develop further insight into the challenges impacting impoverished individuals, the existing structural inequalities impacting impoverished groups and populations, and the policy process at the district, local, regional, and national levels of government in Ghana.

Since the results of this study indicated that students interested in macro social work practice were less likely to attribute poverty to membership in excluded populations, it is important to develop teaching strategies and educational opportunities to increase the understanding and empathy toward oppressed and excluded populations living in poverty. For example, females in Ghana represent an oppressed group. Studies have found that the cultural values in Ghana lead to gender discrimination in education with a higher priority placed on educating male children over female children in order for females to contribute to household chores and learn home-making skills. As a result, females have much lower levels of education, much higher rates of illiteracy than their male counterparts and therefore, higher rates of poverty (Jones \& Chant, 2009). Empathy is essential to an increased understanding of others' experiences and social conditions which can motivate students to become more socially engaged and promote social change (Gerdes, Segal, Jackson, \& Mullins, 2011). Social work educators in Ghana can adapt empathy enhancement strategies that have been demonstrated to be effective in the U.S. to the cultural and social context of Ghana. The use of role playing and Gestalt techniques have been shown to be effective at increasing empathy (Calley \& Gerber, 2008; Pearson, Russ, \& Cain Spannagel, 2008) and can be used to promote opportunities to learn about the lives of females and oppressed and excluded populations living in poverty. Another strategy that can be adapted to fit the cultural and social context of Ghana is the Intergroup Dialogues Method (Nagda et al., 1999) which promotes interactions among students of different social, racial, and class groups in order to develop a greater understanding of issues of discrimination and social justice among various groups.

In addition to the examination of poverty and social welfare policies in the classroom, social work students may benefit from practicum placements that provide them with the opportunity to work directly with individuals, families, and groups experiencing poverty and practioners, policymakers and organizations responsible for developing, implementing, and enforcing social welfare policies and programs intended to alleviate or eliminate poverty. Through this approach social work students may be afforded a more organic and existential experience of what poverty looks and feels like among impoverished populations, as well as the institutional and political challenges 
policymakers and practitioners experience in promoting, developing, and implementing social welfare policies. Given the relationship between values, perceptions, and behavior, providing social work students with these experiences may result in social work students rejecting or modifying existing perceptions toward poverty, poor populations, and social welfare policies.

The findings of this study also point out the need for further research. Refinement of the survey instrument is needed to clarify several of the questions, particularly those questions addressing social work students' socioeconomic status and area of concentration. Further research is needed to explore more directly how social work students' socioeconomic status and area of concentration influence their perceptions toward poverty and social welfare policies in Ghana. Future studies are needed to determine the efficacy of specific classroom and practicum placement experiences in influencing social work students' perceptions toward poverty and social welfare policies. Identifying the perceptions of social work students and other human and social service oriented students would also be beneficial given these groups of students may have direct involvement with poor populations or serve in influential, decision-making positions in the future.

If social work is going to be the leader in ameliorating poverty among individuals, families, communities, and nations, it is imperative that social work students be provided with the opportunity to acquire and practice the knowledge and skills essential to working with poor populations and policymakers and practitioners committed to alleviating and/or eliminating poverty in Ghana. Finally, while the findings presented herein are primarily addressing social work students, faculty members, administrators, and programs in Ghana, the findings may also be of interest to students, faculty members, administrators, and programs outside of Ghana and the social work discipline. Through this international and interdisciplinary exchange, students, faculty members, administrators, and programs across disciplines may exchange information and resources that lead to the development of social welfare policies and programs that contribute to the alleviation and/or elimination of poverty in developing nations, including Ghana.

\section{References}

Adema, W., Gray, D., \& Kahl, S. (2003). Social assistance in Germany (Organisation for Economic and Co-Operation and Development (OECD) Labor Market and Social Policy Occasional Papers No. 58). Retrieved from http://dx.doi.org/10.1787/338133058573

Amu, N. J. (2006). The role of women in Ghana's economy. Retrieved from http://library.fes.de/pdf-files/bueros/ghana/02990.pdf

Apt, N. A. (2007, March). The extra burden of ageing women in a poor economic environment. Paper presented at the International Conference on Population Aging, Brussels, Belgium. Retrieved from http://www.platformpopdev.be/pdf/pres7.pdf

Armah, C. (2009). Poverty as an abuse of human rights in Ghana. A grass root perspectives of on poverty and human rights. (Master's Thesis). Dalarna University, 
Falun, Sweden. Retrieved from http://du.divaportal.org/smash/get/diva2:518925/FULLTEXT01.pdf

Aryeetey, E., \& Goldstein, M. (2000). Ghana: Social policy reform in Africa. In D. A. Morales-Gomez, N. Tschirgi, \& J. L. Moher (Eds.), Reforming social policy: Changing perspectives on sustainable human development (pp. 9-44). Ottawa, Canada: International Development Research Centre.

Asamoah, Y. (1997). Africa. In N. S . Mayadas, D. Elliott, \& T. D. Watts (Eds.), International handbook on social work theory and practice (pp. 303-319). London, UK: Greenwood Press.

Asquith, S., Clark, C., \& Waterhouse, L. (2005). The role of the social worker in the $21^{\text {st }}$ century: A literature review. Retrieved from http://www.scotland.gov.uk/Resource/Doc/47121/0020821.pdf

Avendal, C. (2011). Social work in Ghana: Engaging traditional actors in professional practices. Journal of Comparative Social Work, 2011/2, 1-19. Retrieved from http://jcsw.no/local/media/jcsw/docs/jcsw_issue 2011_2_4 article.pdf

Blavo, E. Q., \& Apt, N. A. (1997). Ghana. In N. S. Mayadas, D. Elliott, \& T. D. Watts (Eds.), International handbook on social work theory and practice (pp. 320-343). London, UK: Greenwood Press.

Breznau, N. (2008). Social welfare and economic equality: An analysis of policy preferences in five nations (Master's Thesis). ProQuest Dissertations and Theses Database. Retrieved from http://search.proquest.com/docview/275984866?accountid=14677

Brown, M., \& Neku, R. J. (2005). A historical review of the South African social welfare system and social work practitioners' views on its current status. International Social Work, 48(3), 301-312. doi: 10.1177/0020872805051733

Bullock, H. E. (2004). From the front lines of welfare reform: An analysis of social worker and welfare recipient attitudes. Journal of Social Psychology, 144(6), 571588. Retrieved from http://web.ebscohost.com/ehost/pdfviewer/pdfviewer?sid=6de4e154-9b66-4dc1b813-2066219f0d19\%40sessionmgr113\&vid=4\&hid=124

Calley, N. C., \& Gerber, S. (2008). Empathy promoting counseling strategies for juvenile sex offenders: A developmental approach. Journal of Addictions and Sexual Counseling, 28(2), 68-85. doi: 10.1002/j.2161-1874.2008.tb00034.x

CIA World Factbook. (2011a). Ghana: Economy. Retrieved from https://www.cia.gov/library/publications/the-world-factbook/geos/gh.html

CIA World Factbook. (2011b). Ghana: Natural resources. Washington, DC: Central Intelligence Agency (CIA). Retrieved from https://www.cia.gov/library/publications/the-world-factbook/fields/2111.html 
Clark, S. (2007). Social work students' perceptions of poverty. Journal of Human Behavior in the Social Environment, 16(1/2), 149-166. doi:10.1300/J137v16n01_10

Devereux, S., Sabates, R., Guenther, B., Dorward, A., Poulton, C., \& Al-Hassan, R. (2008). Linking social protection and support to small farmers development. Paper Commissioned by Food and Agriculture Organization (FAO). Retrieved from http://www.fao.org/fileadmin/templates/esa/Workshop_reports/Social_protection_20 08/workshop_0108_social_protection.pdf

Dollar, D., \& Kraay, A. (2000). Growth is good for the poor. Retrieved from http://siteresources.worldbank.org/DEC/Resources/22015_Growth_is_Good_for_Poo r.pdf

Feagin, J. R. (1975). Introduction. In J. R. Feagin (Ed.), Subordinating the poor: Welfare and American beliefs (pp. i-14). Englewood Cliffs, NJ: Prentice-Hall.

Gerdes, K. E., Segal, E. A., Jackson, K. A., \& Mullins, J. L. (2011). Teaching empathy: A framework rooted in cognitive neuroscience and social justice. Journal of Social Work Education, 47(1), 109-131. doi: 10.5175/JSWE.2011.200900085

Ghana Statistical Service. (2009). Ghana's economic performance, 2009. Retrieved from http://www.statsghana.gov.gh/docfiles/news/gh eco performance 2009 in figures.p $\underline{\mathrm{df}}$

Gobah, F. K., \& Zhang, L. (2011). The National Health Insurance Scheme (NHIS) in Ghana: Prospects and challenges: A cross-sectional evidence. Global Journal of Health Sciences, 3(2), 90-101. doi:10.5539/gjhs.v3n2p90

Hackett, S., Kuronen, M., Matthies, A., \& Kresal, B. (2003). The motivation, professional development and identity of social work students in four European countries. European Journal of Social Work, 6(2), 163-178. doi:10.1080/1369145032000144421

Heintz, J. (2005). Employment, poverty, and gender in Ghana (Working Paper Series No. 42). Retrieved from www.wiego.org/papers/presentations/.../Heintz_Ghana_Labour_Force.ppt

Index Mundi. (2010). Ghana population below poverty line. Retrieved from http://www.indexmundi.com/Ghana/population_below_poverty_line.htm

International Federation of Social Workers. (2012). Code of ethics of the International Federation of Social Workers. Retrieved from http://ifsw.org/policies/code-of-ethics/

International Fund for Agricultural Development (IFAD). (2011). Rural poverty in Ghana. Retrieved from http://www.ruralpovertyportal.org/web/web/guest/country/home/tags/ghana

International Labor Organization. (2006). Working out of poverty in Ghana: The Ghana decent work pilot programme. Retrieved from http://www.ilo.org/wcmsp5/groups/public/@ed_mas/@eval/documents/publication/w cms 116892.pdf 
Jacobson, W. B. (2001). Beyond therapy: Bringing social work back to human services reform. Social Work, 46(1), 51-61. Retrieved from http://web.ebscohost.com/ehost/detail?vid=3\&sid=c2700617-a3bd-42f0-8e7250dad127209b\%40sessionmgr104\&hid=124\&bdata=JnNpdGU9ZWhvc3QtbGl2ZQ $\% 3 \mathrm{~d} \% 3 \mathrm{~d} \# \mathrm{db}=\mathrm{aph} \& \mathrm{AN}=4036076$

Johnson, A. G. (2010). Why is there poverty? Retrieved from http://www.agjohnson.us/essays/poverty/

Jones, G. A., \& Chant, S. (2009). Globalising initiatives for gender equality and poverty reduction: Exploring "failure" with reference to education and work among urban youth in The Gambia and Ghana. Geoforum, 40(2), 184-196. doi:10.1016/j.geoforum.2008.07.008

Kimani, E., \& Kombo, D. (2010). Gender and poverty reduction: A Kenyan context. Educational Research and Reviews, 5(1), 24-30. Retrieved from http://www.ku.ac. ke/images/stories/docs/publications/education/gender_poverty_reduction_publication pdf

Kormey, M. K. (2009). Enhancing the economic security of the Ghanaian worker: The role of the Social Security and National Insurance Trust. Retrieved from http://dspace.knust.edu.gh:8080/jspui/bitstream/123456789/638/1/MICHAEL\%20KI NSLEY\%20KORMEY.pdf

Kreitzer, L. (2004). Indigenization of social work education and practice: A participatory action research project in Ghana. (Unpublished doctoral dissertation). University of Calgary, Alberta, Canada.

Kreitzer, L., Abukari, Z., Antonio, P., Mensah, J., \& Kwaku, A. (2009). Social work in Ghana: A participatory action research project looking at culturally appropriate training and practice. Social Work Education, 28(2), 145-164. doi: 10.1080/02615470 802109973

Laird, S. E. (2011). Social work with children and families in Ghana: Negotiating tradition and modernity. Child and Family Social Work, 16(4), 433-443. doi:10.1111/j.1365-2206.2011.00758.x

Leighninger, L., \& Midgley, J. (1997). North America. In N. S. Mayadas, D. Elliott, \& T. D. Watts (Eds.), International handbook on social work theory and practice (pp. 928). London: Greenwood Press.

Limb, G., \& Organista, K. (2003). Comparisons between Caucasian students, students of color, and American Indian students on their views on social work's traditional mission, career motivations, and practice preferences. Journal of Social Work Education, 39(1), 91-109.

Ljubotina, D. O., \& Ljubotina, D. (2007). Attributions of poverty among social work and non-social work students in Croatia. Croatian Medical Journal, 48(5), 741-749. Retrieved from http://www.ncbi.nlm.nih.gov/pmc/articles/PMC2205978/ 
Manful, S. E., \& Manful, E. (2010). Improving the lives of Ghanaian children: Complementing the global agenda with a structural social work approach. International Journal of Social Welfare, 19(1), 115-123. doi:10.1111/j.14682397.2009.00695.x

Mensah, A. S. (2009). Status of NHIS and new strategic direction. Health summit. Accra, Ghana: Ghana Institute of Management and Public Administration (GIMPA). Retrieved from http://www.scribd.com/doc/55997804/Status-of-Nhis-and-NewStrategic-Direction-by-Mr-Sylvester-a-Mensah

Mensah, J., Oppong, J. R., \& Schmidt, C. M. (2010). Ghana's National Health Insurance Scheme in the context of the health MDGs: An empirical evaluation using propensity score matching. Health Economics, 19(Supplement), 95-106. doi: 10.1002/hec.1633

Midgley, J. (1981). Social work education in the third world. In J. Midgley (Ed.), Professional imperialism: Social work in the third world (pp. 61-84). London: Heinemann Education Books Ltd.

Murray, C. A. (1984). The social scientists and the great experiment. In C. A. Murray (Ed.), Losing ground: American social policy, 1950-1980 (pp. 147-153). New York: Basic Books.

Muuri, A. (2010). The impact of the use of the social welfare services or social security benefits on attitudes to social welfare policies. International Journal of Social Welfare, 19(2), 182-193. doi:10.1111/j.1468-2397.2009.00641.x

Nagda, B. A., Spearmon, M. L., Holley, L. C., Harding, S., Balassone, M. L., MoiseSwanson, D., \& de Mello, S. (1999). Intergroup dialogues: An innovative approach to teaching about diversity and justice in social work programs. Journal of Social Work Education, 35(3), 433-449.

Nasser, R., Abouchedid, K., \& Khashan, H. (2002). Perceptions of the causes of poverty comparing three national groups: Lebanon, Portugal and South Africa. Current Research in Social Psychology, 8(7), 101-119. Retrieved from http://www.uiowa.edu/ grpproc/crisp/crisp.8.7.html

Obeng, S. K. (2008). SSNIT: Its performance and importance to the Ghanaian society. A case study of pensioners and beneficiaries of SSNIT at La-Accra. Retrieved from http://img.modernghana.com/images/content/report_content/ITS\%20PERFORMAN CE\%20AND\%20IMPORTANCE\%20TO\%20THE\%20GHANAIAN\%20SOCIETY. pdf

Otlin, J. (2008). The causes of poverty: Thinking critically about a key economic issues. Social Education, 72(2), 75-79. Retrieved from www.socialstudies.org/system/files/publications/se/7202/720275.pdf

Owusu, V., \& Abdulai, A. (2009, August). Non-farm employment and poverty reduction in rural Ghana: A propensity-score matching analysis. Paper presented at the International Association of Agricultural Economists Conference, Beijing, China. Retrieved from http://purl.umn.edu/51363 
Pearson, B. L., Russ, S. W., \& Cain Spannagel, S. A. (2008). Pretend play and positive psychology: Natural companions. Journal of Positive Psychology, 3(2), 110-119. doi:10.1080/17439760701760617

Perbi, Y. (2004). A++ maximising your tertiary education—and loving it. Montreal, Canada: The HuD Group Canada.

Rolleston, C. (2011). Educational access and poverty reduction: The case of Ghana 1991-2006. International Journal of Educational Development, 31(4), 338-349. doi: 10.1016/j.ijedudev.2011.01.002

Social Security and National Insurance Trust. (2011). Homepage. Retrieved from http://www.ssnit.com/

Sowa, N. K. (2002, January). Assessment of poverty reducing policies and programmes in Ghana. Paper presented at MIMAP Workshop, Rabat, Morocco. Retrieved from http://www.cepa.org.gh/researchpapers/Assessing\%20Poverty\%20Programs\%20and \%20Policies\%20in\%20Ghana54.pdf

Sultan, M. S., \& Schrofer, T. T. (2008, September). Building support to have targeted social protection interventions for the poorest - The case of Ghana. Paper presented at the International Conference on Social Protection, Kampala, Uganda. Retrieved from http://www.unicef.org/socialpolicy/files/Social Protection for the Poorest Ghana.pdf

Takyi, B. K., Obeng-Gyimah, S., \& Addai, I. (2006, March). Religion and fertility behavior of married men and women: An empirical examination of data from Ghana, sub-Saharan Africa. Paper presented at the annual meeting of the Population Association of America, Los Angeles, CA. Retrieved from http://paa2006.princeton.edu/papers/61053

Tam, T. K. (2003). Humanitarian attitudes and support of government responsibility for social welfare: A study of perceptions of social work graduates in Hong Kong and the People's Republic of China. International Social Work, 46(4), 449-467. doi: 10.1177/0020872803464003

Tanner, M. (2012). The American welfare state. How we spend nearly \$1 trillion a year fighting poverty — and fail (Policy Analysis No. 694). Retrieved from http://heartland.org/sites/default/files/pa694.pdf

Throup, D. W. (2011). Ghana: Assessing risks to stability. Washington, DC: Center for Strategic and International Studies. Retrieved from http://csis.org/files/publication/110623 Throup_Ghana_Web.pdf

United States Agency for International Development. (2010). Sub-Saharan Africa; Ghana. Retrieved from http://www.usaid.gov/locations/subsaharan_africa/countries/ghana/

Weaver, D. R., \& Yun, S. H. (2010). Social work students' attitude toward poverty in the new economy: A multivariate analysis. US-China Education Review, 7(5), 34-46. Retrieved from http://www.davidpublishing.com/show.html?6041 
Weiss, I. (2003). Social work students and social change: On the link between views on poverty, social work goals and policy practice. International Journal of Social Welfare, 12(2), 132-141. doi:10.1111/1468-2397.00251

Weiss, I. (2005). Is there a global common core to social work? A cross-national comparative study of BSW graduate students. Social Work, 50(2), 101-110.

Weiss, I. (2006). Factors associated with interest in working with the poor. Families in Society, 87(3), 385-394. doi: 10.1606/1044-3894.3543

Weis, I., Cnaan, R. A., \& Gal, J. (2005). Does social work education have an impact on social policy preferences? A three-cohort study. Journal of Social Work Education, 41(1), 29-47. doi: 10.5175/JSWE.2005.200202148

Weiss, I., Gal, J., \& Cnaan, R. A. (2004). Social work education as professional socialization: A study of the impact of social work education upon students' professional preferences. Journal of Social Service Research, 31(1), 13-31. doi:10.1300/J079v31n01_02

Weiss, I., Gal, J., Cnaan, R., \& Majiaglic, R. (2002). What kind of social policy do social work students prefer? A comparison of students in three countries. International Social Work, 45(1), 59-81. doi:10.1177/0020872802045001320

Whitefield, L. (2009). The new 'New poverty agenda' in Ghana: What impact? (Working Paper No. 15). Retrieved from http://hdl.handle.net/10419/44702

Woodcock, J., \& Dixon, J. (2005). Professional ideologies and preferences in social work: A British study in global perspective. British Journal of Social Work, 35(6), 953-973. doi:10.1093/bjsw/bch282

World Health Organization. (2009). Country cooperation strategy at a glance: Ghana. Retrieved from http://www.who.int/countries/gha/gha/en/

\section{Author note:}

Address correspondence to: Jason T. Castillo, PhD., Assistant Professor, College of Social Work, University of Utah, 395 South 1500 East, Salt Lake City, UT 84112. Email: jason.castillo@socwk.utah.edu 